\title{
Landscape Design Project of Historical Yedikule Gardens (Istanbul)
}

\author{
Nurhan KOÇAN ${ }^{1}$, Gökhan BALIK ${ }^{2 *}$
}

\begin{abstract}
Urban agriculture has been an important issue throughout the history as an economic and leisure time effort. Also urban agriculture has played an important role in increasing the quality of urban life in ecological terms by contributing to the urban green space system. Historical Yedikule Gardens was chosen as a study area in order to embody these important roles of urban agriculture on an example and incorporate it in today's experience. The study area has history of 1500 years in the borders of Istanbul Fatih District. This area is considered as one of the most basic examples of urban agriculture. People have been producing and selling vegetables and fruits in this area for hundreds of years. With this work, it was aimed to reorganize Historical Yedikule Farmland to increase the contribution of the area to the texture of the urban green area with its renewed landscape and to provide economic gain and hobby area to the city people while maintaining a past culture. In this context, the landscape design project of the study area was carried out within the scope of historical environmental protection and urban agriculture area regulation principles. In the result of the work it is seen that the area renewed as historical, cultural and economic values will be contribution to the users of and the city. The study can be an example of such similar areas in terms of urban green space system and community use.
\end{abstract}

Keywords: Urban agriculture, Urban green space, Open space, Landscape design, Historical Yedikule Gardens.

\section{Tarihi Yedikule Bostanları (İstanbul) Peyzaj Tasarım Projesi}

\section{$\ddot{O} z$}

Kentsel tarım kent halkının gerek ekonomik gerekse bir serbest zaman uğraşısı olarak tarih boyunca önemini koruyan bir konu olmuştur. Bununla birlikte kentsel tarım, kentsel yeşil alan sistemine katkısı ile ekolojik anlamda kentsel yaşam kalitesinin artırılmasında önemli rol oynamıştır. Kentsel tarım alanlarının bu önemli rollerini bir örnek üzerinde somutlaştırmak ve günümüz yaşantısına dahil etmek amacıyla Tarihi Yedikule Bostanları çalışma alanı olarak seçilmiştir. Çalışma alanı İstanbul İli Fatih İlçesi sınırları içinde 1500 yıllık geçmişe sahip bir alandır. Bu alan kentsel tarımın en temel örneklerinden biri olarak kabul edilmektedir. İnsanlar yüzlerce yıl bu alanda sebze-meyve üretimi ve satışı yapmışlardır. Bu çalışmayla Tarihi Yedikule Bostanlarını yeniden düzenlemek, yenilenen çehresiyle alanın kentsel yeşil alan dokusuna katkısını artırmak, geçmiş bir kültürü devam ettirirken kent halkına ekonomik kazanç ve hobi alanı kazandırmak hedeflenmiştir. Bu kapsamda tarihi çevre koruma ve kentsel tarım alanı düzenleme ilkeleri kapsamında çalışma alanının peyzaj tasarım projesi yapılmıştır. Çalışmanın tarihi, kültürel ve ekonomik değerleriyle yenilenen alana, alan kullanıcılarına ve kente katkısı olacağı sonucuna varılmıştır. Çalışma buna benzer alanların kentsel yeşil alan sistemi ve toplum kullanıma kazandırılması yönünde örnek olabilecek niteliktedir.

Anahtar Kelimeler: Kentsel tarım, Kentsel yeşil alan, Açık alan, Peyzaj tasarımı, Tarihi Yedikule Bostanları

\footnotetext{
${ }^{1}$ Bartın University, Department of Landscape Architecture, Bartın, Turkey, nkocan@bartin.edu.tr

${ }^{2}$ Trakya University, Department of Landscape Architecture, Edirne, Turkey, gokhanbalik@trakya.edu.tr
} 


\section{Introduction}

Urban agriculture is the total of agricultural activities in the city and its periphery involving production, distribution and marketing of food and other related products in the central areas of the metropolis (Steward et. al, 2007). Urban agriculture is applied in an integrated manner with the city throughout the history. In Garden city theory of Ebenezer Howard, 5/6 of the land is divided into agricultural activities (Howard, 1965). Howard often shows a city of urban and agriculture mix as the ideal city (TSKB, 2021). In 1922, with the proposal of Contemporary City, Le Corbusier divided the city into three different food production areas and proposed a model for management and control of the land (Le Courbusier, 1987). Despite that, urban agriculture continued to today.

Recently, within the concept of sustainable development; the protection and development of land and agriculture farm natural sources and the provision of food safety for health are among the important topics for sustainable communities. It is argued that urban agriculture should be supported because of its positive effects on economic, social and environmental dimensions (Ernwein, 2014). Activities such as the production, processing, selling, cooking and recycling of local food are economically beneficial for families, promoting social inclusion and adaptation and also manifesting the cultural aspects of nutrition (TSKB, 2021). The research conducted by various organizations, such as WHO, FAO, UNICEF and APA in recent years, show that urban agriculture provides a healthy and financially affordable food for low-income families and individuals, particularly those with limited access to food by increasing accessibility to fresh vegetables and fruits. Urban agriculture also creates social awareness through health programs and raises awareness in nutrition issues (FAO, 1996; Bellows et. al., 2004).

Urban agriculture has a therapeutic value. In this category, it is beneficial for educational programs for special groups such as children, teenagers, adults, homeless or criminals (Hodgson et. al., 2011). Urban agriculture is an alternative in terms of reusing vacant land by providing mutual responsibility, trust, sharing, peace and friendship and social development therefore, reducing the risks that are endangering society such as crime processing and illegal garbage accumulation (Kaufman and Bailkey, 2000; Bellows et al., 2004; Lyson, 2005; Veenhuizen, 2006; Teig et al., 2009).

Urban agriculture can contribute to productive restoration of polluted lands especially in terms of environmental management. By means of the increased vegetation coverage, urban agriculture contributes to the reduction of rainwater runoff and air pollution, increasing urban biodiversity and helping to protect species and integrate urban green areas (Kaufman and Bailkey, 2000; Veenhuizen, 2006).

The urban agriculture is based on place, ecological sensitivity, economic efficiency, social integration and confidence in food production (Table 1), (TSKB, 2021). 
Table 1: Urban agriculture typologies (APA, 2007; TSKB, 2021).

\begin{tabular}{|c|c|c|}
\hline CATEGORY & SPECIES & EXPLANATION \\
\hline \multirow{7}{*}{ 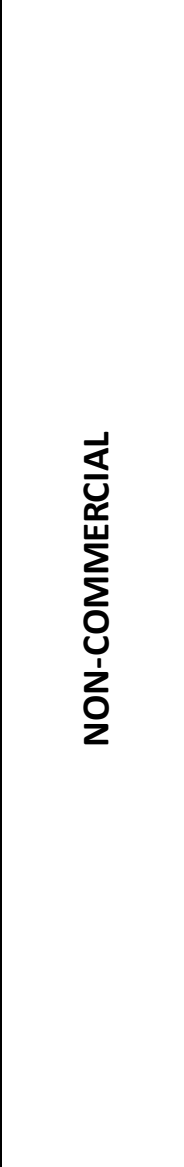 } & $\begin{array}{l}\text { Special } \\
\text { Gates }\end{array}$ & $\begin{array}{l}\text { The activity of food production or personal work in front or back garden, } \\
\text { roof, balcony, wall edge, glass edge and basement of single or multi } \\
\text { family residence. Crops are generally used for personal consumption. }\end{array}$ \\
\hline & $\begin{array}{l}\text { Community } \\
\text { Gardens }\end{array}$ & $\begin{array}{l}\text { Gardens for producing food and ornamental plants in small or medium } \\
\text { sized residential areas are adjoining or discrete parcels. They are } \\
\text { cultivated and managed by groups of people on public or private lands. }\end{array}$ \\
\hline & $\begin{array}{l}\text { Corporate } \\
\text { Gardens }\end{array}$ & $\begin{array}{l}\text { Small, medium or large food production, ornamental plant garden or fruit } \\
\text { garden. The institution or workplace on the premises of private or } \\
\text { publicly owned institutions manages them. They are for educational, } \\
\text { therapeutic or public service purposes. The products are for donation and } \\
\text { personal consumption. }\end{array}$ \\
\hline & $\begin{array}{l}\text { Display } \\
\text { Gardens }\end{array}$ & $\begin{array}{l}\text { Local governments, institutions or businesses for demonstration in } \\
\text { private or public spaces build small-scale food production gardens. Crops } \\
\text { are generally produced for donation. }\end{array}$ \\
\hline & $\begin{array}{l}\text { Edible } \\
\text { Landscape }\end{array}$ & $\begin{array}{l}\text { In residential, commercial and mixed-use areas. Landscape objects and } \\
\text { agricultural products can generally be consumed by visitors. }\end{array}$ \\
\hline & $\begin{array}{l}\text { Do-it- } \\
\text { yourself } \\
\text { Gardens } \\
\end{array}$ & $\begin{array}{l}\text { Unauthorized activities by people or groups to raise food production or } \\
\text { ornamental plants in abandoned or vacant areas. Agricultural products } \\
\text { usually revitalize the area. }\end{array}$ \\
\hline & $\begin{array}{l}\text { Allotment } \\
\text { gardens }\end{array}$ & $\begin{array}{l}\text { Made for personal uses in small size private gardens, plots, parks or } \\
\text { fences. The agricultural products are for personal consumption, } \\
\text { education or donation. }\end{array}$ \\
\hline \multirow{2}{*}{ 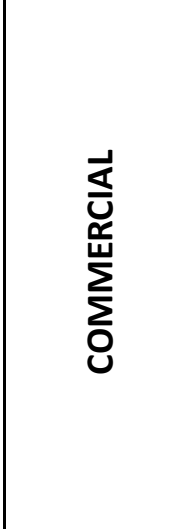 } & $\begin{array}{l}\text { Market } \\
\text { Oriented } \\
\text { Agriculture }\end{array}$ & $\begin{array}{l}\text { Food production for trade or cultivation of ornamental plants, } \\
\text { beekeeping, aquaculture and animal husbandry are carried out In private } \\
\text { or public places, using various production techniques such as soil, } \\
\text { landless, container, etc.,. The markets or stores sell the grown plants in } \\
\text { the field. }\end{array}$ \\
\hline & City Farm & $\begin{array}{l}\text { Ornamental plants, beekeeping, aquaculture and animal husbandry are } \\
\text { the activities in addition to food production. The farms are to trade on a } \\
\text { larger scale than market farms. Contain grounded, soilless, container and } \\
\text { hydroponic breeding systems. Agricultural products are usually sold in } \\
\text { farms or on non-farm countertops, markets or in stores. }\end{array}$ \\
\hline
\end{tabular}

In recent years, industrialization has led to an increase in the inner-urban land values, the affordability of agriculture for low budgets, as well as the allocation of activities in urbans with higher economic incentives. Even in the densest areas of metropolitans, there are potential areas for a wide variety of urban agriculture activities but agricultural habits have been lost in these areas. Urban agriculture is a valuable effective planning and design tool and it is also an innovative approach from economic, ecological and social aspects. This includes the inclusion of a green system for the 
protection of urban farming areas and developing the allotment gardens, etc. for recreational purposes by converting into activity areas (Gorgolewski et al., 2011).

Historical Yedikule Gardens is a case study area in order to embody the above-mentioned important roles of urban agriculture on an example and incorporate it in a current experience. The case study area has history of 1500 years in the borders of Istanbul Fatih District. This area is one of the most basic examples of urban agriculture. People have been producing and selling vegetables and fruits in this area for hundreds of years. Our aim in this paper is to reorganize Historical Yedikule Gardens: 1. To increase the user population of the case study area and adding it to the texture of the urban green space, 2. To provide economical income and maintain the past culture with allotment gardens and other activities. In this context, the landscape design project of the study area was carried out within the scope of historical environmental protection and urban agriculture area regulation principles.

\section{Materials and Methods}

Historical Yedikule Gardens as the case study area, is one of the neighborhoods of Fatih District of Istanbul. The population of Fatih District is 417.285 in 2016 (URL1). Yedikule is an old Greek neighborhood located on the shores of Marmara Sea between Kocamustafapaşa and Zeytinburnu's Kazliçeşme districts of Fatih. Its name comes from the seven towers of the city walls surrounding the historical peninsula. The Historical Yedikule Gardens is located in the the conservation zone of city walls of Istanbul that was built during the Byzantine period with a history of more than 1500 years. The Gardens are also in UNESCO World Heritage List (Arkitera, 2016).

Yedikule Gardens is a part of the urban culture and the first urban agriculture area in history of Istanbul (Figure 1, 2).

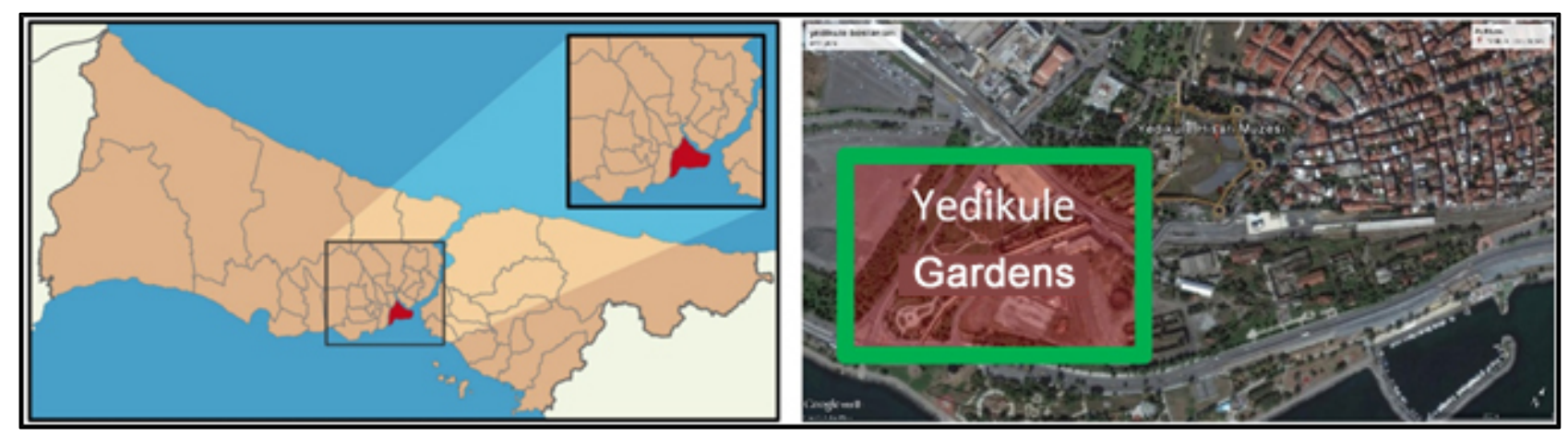

Figure 1. The location of the Yedikule Gardens (Wikipedia, 2021; Google Earth, 2021). 


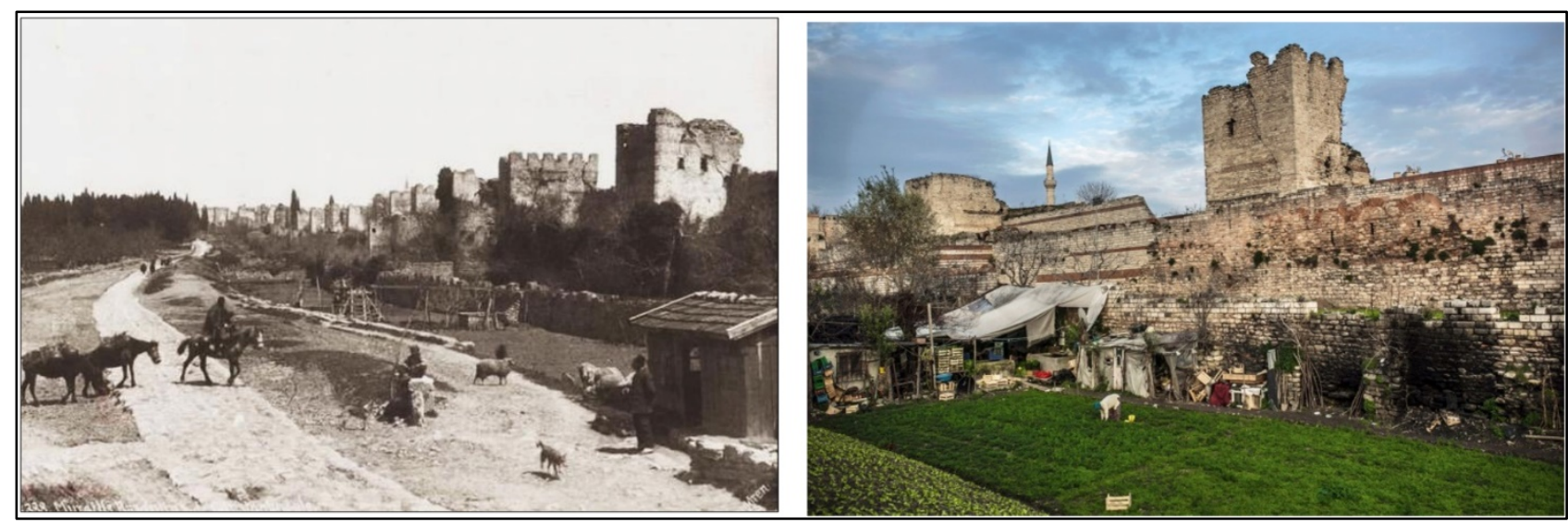

Figure 2. The old (1920) and new appearance of the Historical Yedikule Gardens (Baser and Esbah Tuncay, 2010; Atlas Magazine, 2016).

The history of the circumscribing the wall dates back to the 18th century. Alexander Van Millingen wrote in a book in 1899 that the Turks filled the alongside of the walls with agricultural areas in time after the conquest of Istanbul. The gardens in the country are located on the full agricultural area. For this reason, the history of the lands began during the Ottoman period (Arkitera, 2016). In Yedikule Gardens, the pools, wells and booster rooms are the structures from the beginning of the 18th century. At that time, the city walls and fortifications were very important for the defense of the city (TSKB, 2021).

In addition to exceptional conditions, there is no construction on the streets along the city wall. Yedikule Gardens has been in the center of Istanbul for centuries for meeting the needs of the city for green space and agricultural production/vegetables. In the Ottoman period, agricultural production was allowed alongside the city wall (Arkitera, 2016). Many plants such as peppermint, parsley, curly salad, lettuce, leek, red pepper, white cabbage, tomato, pepper, eggplant grow in Yedikule Gardens.

In the case study area, the land use data, historical and recent data and observations were evaluated for survey and analyses. After the analyses, the landscape project was designed within the scope of historical environmental protection and design principles of the urban agriculture areas.

In this paper, the cultural values of the city, such as the historical past of the area, as well as the natural values of the city, its location, natural vegetation were evaluated during the survey phase of the project. The design baselines of the project were created with hand-drawings. AutoCAD and Sketch Up computer software were used for project presentations and 3d images (Figure 3).

In this context, items such as open, semi-open living and resting areas, fruit and vegetable gardens, promenades, basic requirement areas such as buffets, WCs, parking lots, exhibition areas, assembly areas were added to the project. The historical and cultural structure, natural features of the area, basic needs of visitors and similar projects were effective in determining the program units. 


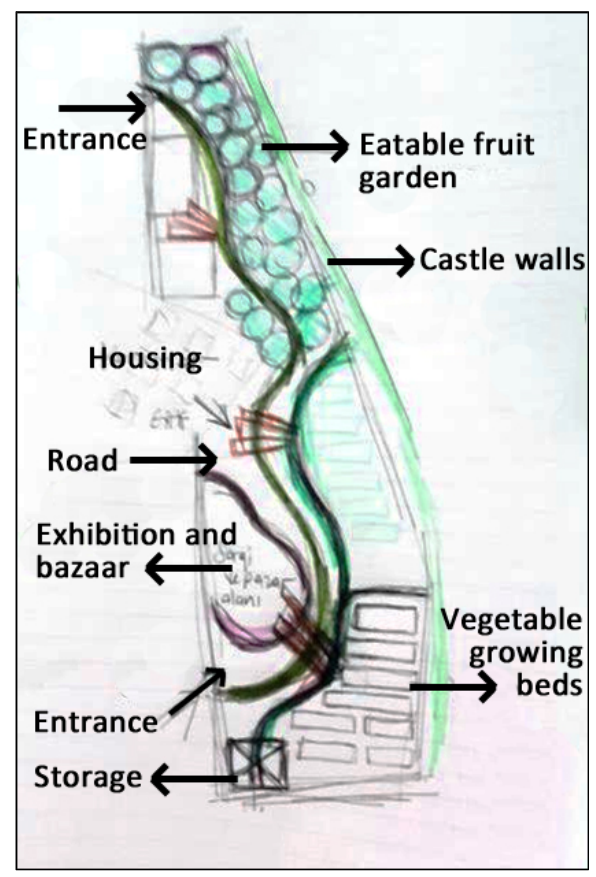

Figure 3. The landscape design project formation phases of Historical Yedikule Gardens

\section{Results and Discussion}

\section{The Purpose and Goal of the Yedikule Gardens Design Project}

The purpose and goal of the suggested project is to renew the area that has 1500 years of history and to combine modern and historical forms, ideas and concepts within the respect to the historical environmental protection and regulatory principles. With this project, people will have the opportunity to experience activities such as recreation in the urban environment while experiencing the historical side of Yedikule Gardens at the same time.

\section{Concept: Cultural Recycling}

Despite the negative effects of the residential development, the ecologically insensitive uses and the incorrectly planned projects, the case study area is desired to recover from the effects of past mistakes with this project. With the concept of "Cultural Recycling", it is underlined that the area was once a horticulture and returnable value to its historical use. With this project, it is clear that the green areas which existed long before and were removed from the master plan can be recovered. Besides, the past culture of urban agriculture and social evolvement can be revitalized. In order to save the urban areas that are devaluing, new cultural, social and economic functions need to be reestablished. Cultural functions are appropriate choices for these culturally important areas (Tatlican, 2006). 


\section{The Planning Decisions}

The planning decisions are:

- Identifying areas that are sensitive to natural and environmental values within the conserve-use balance,

- Determining the potential of the user,

- Planning appropriately for ecological and economical agriculture,

- Ensuring the sustainability of urban agriculture,

- Restoring historical identity, to pass it on to future generations,

- Protecting and integrating with historical walls,

- $\quad$ Reconciling the open green areas around the area for urban green connections.

\section{The Design Principles}

- Designing with the combination of modern lines and historical context.

- The usage of the area was designed with consideration for compatibility with the historical walls.

- $\quad$ Easy-to-maintain species have been selected for plant species to be used.

- The design is considered in harmony with the concept up to the vegetable and structural elements.

- The sales points of vegetables and fruits were renovated with physical appearance and restored to standard measures.

- Buildings to be used as depots have been considered.

- The Drainage and irrigation systems should not damage the infrastructure of the historical walls.

- Appropriate urban equipments and furnitures are suggested for user potential (Figure 4).

\section{Suggested Plants for the Fruit Garden}

$\begin{array}{llll}\text { Cydonia oblonga } & \text { Diospyros kaki } & \text { Malus communis } & \text { Morus alba } \\ \text { Morus nigra } & \text { Pyrus communis } & \text { Prunus avium } & \text { Prunus cerasifera } \\ \text { Prunus cerasus } & \text { Prunus domestica } & \text { Prunus spinosa } & \text { Ribes uva-crispa }\end{array}$




\section{Suggested Plants for the Aromatic Garden}

Eucalyptus sp. Laurus nobilis Lavandula sp. Ocimum basilicum

Rosa sp.

Rosmanirus officinalis Salvia officinalis

Thymus sp.

\section{Other Suggested Plants}

Acer palmatum

Cercis siliquastrum
Aesculus hippocastanum

Quercus robur
Albizzia julibrissin

Salix babylonica
Carpinus betulus

Tilia cordata

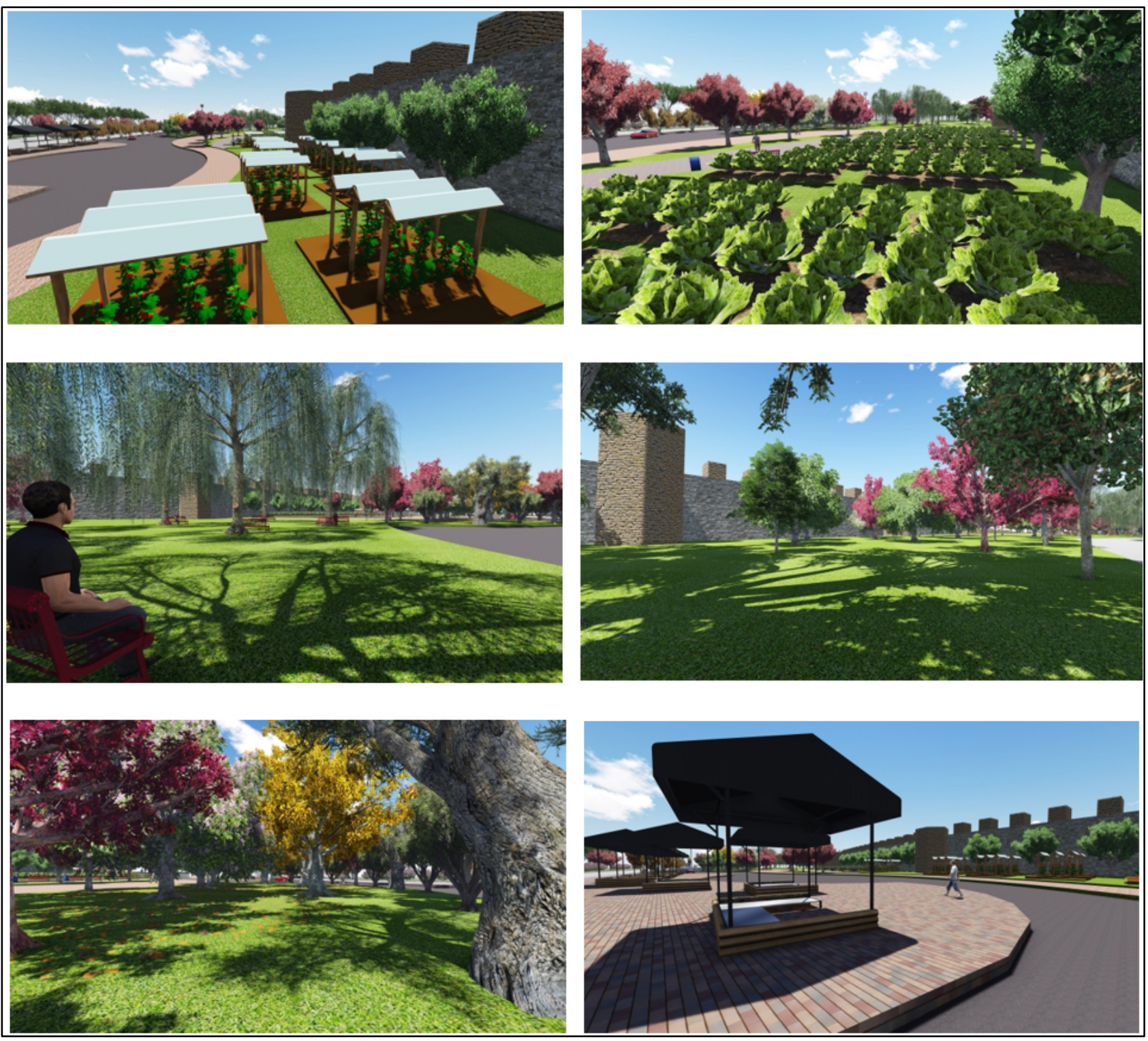

Figure 4. 3d visual samples of Historical Yedikule Gardens landscape project 
The primary goal of planners and designers' for nature and society is to consider the most consistent and most productive forms of the natural environment. The protection of an optimal combination of ecological and aesthetic use of land and to provide ecological and landscape diversity are necessary ways for the social, economic and ecological assets in planning and design (Van der Ryn, 1996). The strategies of our method aims to enhance the social, cultural, economic and ecological assets of Yedikule Gardens and the surrounding area. Besides, if implemented, this can be a pilot project to be a first example for other historical cities of Turkey.

The proposals in this paper are suitable with the urban agriculture strategies of Danube Transnational Programme (Buic et al., 2017). In the action plan guidelines of Danube Transnational Programme, the participatory planning is considered important as the system carries on and develops with social bonds and volunteering. In our project, we did not have time or resources for other disciplines to join or for public participation. The views of other disciplines and public participation have the potential to open up new and better solutions and dimensions.

\section{Conclusion}

A design project of Historical Yedikule Gardens has the potential of re-creating the spirit of place and culture. Besides, it can provide a physical and spiritual renewal for the city people that lost the contact with the nature at the age of technology. Many young people do not know the value of their cultural heritage. Many people living in the cities have the habit of eating processed foods than eating natural vegetables and fruits. Historical, physical, social and economic history of the gardens will at least partially renewal and alleviate some negativities on their sides. In this respect, the provision of necessary education and infrastructure facilities in health, nutrition and culture issues by governments and non-governmental organizations has an important role.

It will be possible to reduce the environmental problems faced by urban areas with urban farming practices and to make agriculture production sustainable by protecting agricultural lands. Thus, sustainable cities that can self-feed while providing food sanitation and security in cities will also provide income security by creating employment with economic contributions.

Landscape designs are effective in protecting the natural and cultural values of the area where they are applied in. They provide maintaining the usage and sustainability of the area. They prevent damaging the area from unsuitable use of nature areas. They have many positive effects on the visitors and the locals. Especially in big cities, it is important to create such areas for people who do not have enough green space and are disconnected from nature. Improving and continuing the existing ones they provide many benefit. In recent years, access to organic vegetables and fruits has become an issue that many people pay attention to. This consciousness, which has been brought to children and 
young people from earlier by touching and seeing in such environments in the city. Many people from young generation does not know neither the vegetable or fruit plants nor the effort and culture of local farming and selling. Thus healthy food and healthy environmental approaches to become the basis. With this aspect, this paper aims to be a reference in such means.

\section{Authors' Contributions}

Assoc. Prof. Dr. Nurhan Koçan did most of the work. Dr. Gökhan Balık edited and corrected the paper.

\section{Statement of Conflicts of Interest}

There is no conflict of interest between the authors.

\section{Statement of Research and Publication Ethics}

The author declares that this study complies with Research and Publication Ethics.

\section{References}

American Planning Association (APA) (2007). Policy Guide on Community and Regional Food Planning. Retrieved: September 17, 2011, from www.planning.org/policy/guides/adopted/food.htm

Arkitera (2016, January 25). Yedikule Bostanlart: Bostancılar Tedirgin, Uzmanlar Uyarlyor. Retrieved: August 26, 2019, from https://www.arkitera.com/haber/yedikule-bostanlari-bostancilar-tedirginuzmanlar-uyariyor/

Atlas Magazine (2016, January 15). Yedikule Bostanlart; Mirasin Talanı. Retrieved: August 26, 2019, from https://www.atlasdergisi.com/gundem/yedikule-bostanlari-mirasin-talani-2.html

Baser, B. and Esbah Tuncay, H. (2010). Understanding the Spatial and Historical Characteristics of Agricultural Landscapes in Istanbul. ITU J Faculty Arch. 2010; 7(2): 106-120.

Bellows, A.C., Brown, K. and Smit, J. (2004). Health Benefits of Urban Agriculture, Community Food Security Coalition, The North American Urban and Peri-Urban Agriculture Alliance, 13.09.2011, from http://www.foodsecurity.org/NAUPAA_description_Nov_2007.pdf

Buic, M., Cunk, K., Kozina, J., Kumer, P., Kozlan, A., Lintzmeyer, F., Luccarelli, A., Istenic, S. P., Schwarz, C., Straus, M., Szalok, M., Vacokova, L., Hribar, M. S., Kladnik, D., Tiran, J. and Zamfira, R. (2017). Approaching urban agriculture as a social innovation: Guidelines for the development and implementation of an action plan. Association for Culture and Education PiNA, Interreg, Danube Transnational Programme, AgriGo4Cities, 62, Koper.

Ernwein, M. (2014). Framing Urban Gardening and Agriculture: On Space, Scale and The Public, Geoforum, Vol. 56, pp.77-86.

FAO (1996). Urban agriculture: An oximoron? In The state of food and agriculture, Food and Agriculture Organization, Rome, 43-57.

Google Earth. (2021, April 07). The Satellite View of Yedikule Gardens, Retrieved: 07.04.2021.

Gorgolewski, M., Komisar, J. and Nasr, J. (2011). Carrot City Creating Places for Urban Agriculture, Random House, Inc., NY. 
Hodgson, K., Campbell, M.C. and Bailkey, M. (2011). Urban Agriculture: Growing Healthy, Sustainable Places, American Planning Association, Planning Advisory Service Report, 563, Chicago, IL.

Howard, E. (1965). Garden Cities of To-Morrow, Cambridge, Mass., M.I.T. Press.

Kaufman, J. and Bailkey, M. (2000). Farming Inside Cities: Entreprenneurial Urban Agriculture in the United States, Lincoln Institute of Land Policy Working Paper, 14.03.2011, from www.lincolnist.edu/pubs/d1/95_Kaufmanbaikey00.pdf.

Le Courbusier, (1987). The City of To-Morrow and Its Planning, New York, Dover Publications.

Lyson, T.A. (2005). Civic Agriculture and Community Problem Solvind, Culture and Agriculture, 27(2), 9298.

Steward, C., Schiavoni, C., Mann, P., Chrismna, S. (2007). Fueling Disaster: A Community Food Security Perspective on Agrofuels, A report by the Community Food Security Coalition International Links Committee, August 30, 2019, from http://foodsecurity.org/Fueling_Disaster.pdf

Tatlıcan, G. (2006). Kentsel koruma alanlarının yaşatılmasında kültürel yatırımların önemi, İstanbul Fener ve Balat Semtleri örneği, unpublished master thesis, Mimar Sinan Fine Arts University, Graduate School of Natural and Applied Sciences, Istanbul, 153.

Teig, E., Amulya, J., Bardwell, L., Buchenau, M., Marshall, J. A. and Litt. J.S. (2009). Collective Efficacy in Denver, Colorado: Strengthening Neighborhoods and Health through Community Gardens, Health \& Place, 15(4), 1115-22.

TSKB (2021, April 12). Kent topraklarının tarımsal amaçlı kullanımı: Kentsel Tarım. Turkish Healthy Cities Association. Retrieved: April 12, 2021, from http://www.skb.gov.tr/kent-topraklarinin-tarimsal-amaclikullanimi-kentsel-tarim-s1238k/

URL1 (2021, May 03). Fatih. Retrieved: May 03, 2020, from https://tr.wikipedia.org/wiki/Fatih

Van der Ryn, S., Cowan, S., Ecological Design, Island Pres, 202 p., California, 1996.

Veenhuizen, R.V. (2006) Cities Farming for the Future: Urban Agriculture for Green and Productive Cities, Silang, Cavite (Philippines), International Institute of Rurel Reconstruction and ETC Urban Agriculture, 05.08.2011, www.idrc.ca/openebook/216-3.

Wikipedia (2021, 03 05). İstanbul Fatih ilçesinin konumu. Retrieved: May 03, 2021, from https://tr.wikipedia.org/wiki/\%C3\%87apa,_Fatih\#/media/Dosya:Istanbul_location_Fatih.svg. 